\title{
Novel Techniques in Post Harvest Management of Mango- An Overview
}

\author{
Krishna Kumar Patel*2, M. A. Khan ${ }^{1}$, Yogesh Kumar² and Arun Kumar Yadav \\ ${ }^{1}$ Deptt. of Post Harvest Engineering and Technology, A.M.U., Aligarh 202002 (India) \\ ${ }^{2}$ Faculty of Agricultural Sciences, Post Graduate College Ghazipur-233001 (India) \\ *Email: k_krishna_374@yahoo.co.in
}

\begin{abstract}
Proper post- harvest operations and handling practices of mango (Mangifera Indica L.) fruit is as importance to provide outstanding quality in market as pre-harvest operations for the good quality mangoes production. Pre-cooling, sorting and grading, packaging, storage, transportation, etc practices of mangoes are very important to control the fruit's quality deterioration. The proper post harvest management also maintains the quality parameters of mangoes such as total soluble solids ( $\left.{ }^{\circ} \mathrm{Brix}\right)$, fruit's maturity, colour, size, sweetness, over/under ripe, etc as per consumer demands and for the minimization of the losses. In addition, another cause/factor of deterioration in fruit's quality and market value is defects and disease during pre-and-post harvest operations. Anthracnose (black lesion), Latex burn (staining), Stem end rot, Chilling injury, Alternaria rot, etc. are among them. Thus, to achieve optimum quality of mango fruit before the exporting, various operations and treatments should be applied under the scientific supervision. This paper reports the various novel-techniques applied in post harvest operations of mango fruit and recent work on its quality management.
\end{abstract}

Keywords: Mango, post-harvest, operations, quality, management, novel-techniques

Paper cited: Patel, K.K., Khan, M.A., Kumar, Y. and Yadav, A.K. (2019). Novel techniques in post harvest management of mango-An overview. South Asian Journal of Food Technology and Environment, 5(2): 821-835.

\section{Introduction}

The king of fruit mango is very rich not only in taste and flavour but also in medicinal values. Most of the mango eater likes mango fruit because of its luscious taste. Southern Asia (mainly eastern India and Burma), the native place mango fruit, was spreaded its cultivation to other countries (Jagtiani et al., 1988; Patel et al., 2019a). Mango is, now, growing in more than 100 countries after spreading outside of India. The production of many countries is greater than 1,000 MT a year (Mitra, 2016). With an estimated output of 18.5 million tonnes in 2017, India ranks first in area (2.31 million ha) and production, and currently accounts for approximately 40 percent of total global production (FAO, 2017). In India about every states are now cultivating mangoes. Production of mangoes from some states of India has been given in the Table 1a. Fruit characteristics of some exporting mango cultivars in India (Anon, 2001) are given in Table $1 b$.

The high qualities of medicinal and nutritional values and unique taste of mangoes increased its commercial value not only in domestic market but also at international marketing platform. Mango is liked by people for its rich luscious aromatic flavour and a delicious taste with evenly blended sweetness and acidity. Nutritionally, Table 2 , it is a rich source of prebiotic dietary fiber, carotenoids, organic acids, polyphenols, provitamins, minerals, etc. (Anon, 2001). Indian mangoes (fresh) exported to several countries including Gulf countries. The effort of Indian Government is to fully utilize the American, Asian and European markets. Besides these, various products of mangoes (raw/ripe) are exported to the Kuwait, Russia and western countries. Mangoes are consumed not only ripe form but also in the form of athanu, chutneys, powder, pickles, side dishes, etc. 
prepared from raw mature fruits. Panna or panha, a summer cooling drink, prepared from raw mango is also very popular among the mango eater. Raw mango, in addition, mar also be eaten with salt, chili and or/soya sauce.

In spite of huge production, deliciousness, rich in vitamins, minerals and anti-oxidants, mangoes also have enzyme with stomach soothing properties. More than 25\% mangoes are spoiled in India because of lack of proper postharvest management technique. Thus the main goal of this study is to report the recent studies on post-harvest operations and management of mangoes.
Post-harvest management before marketing Proper handling of agricultural produce to maintain its quality, freshness and to prolong the shelf life after harvest before marketing is termed as postharvest management (GOI, 2013) to enhance market value. Operations such as sorting, grading, pre-cooling / washing, packaging, storage, transportation, marketing, etc. (Fig. 1) are reported very important after postharvest of mangoes (Anon, 2016). Another operation curing, spreading of fruits on paddy straw cushion floor in the orchard's yard far nearly $24 \mathrm{hrs}$ then washing of fruit to remove dirt, has been reported very crucial in extending the shelf life by GOI (2013).

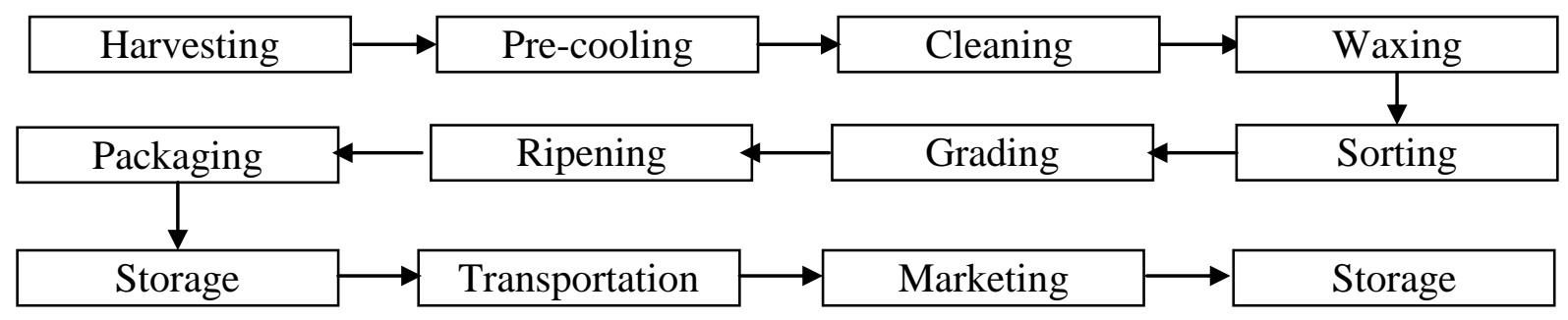

Fig. 1 Steps for post-harvest management of mango

\section{Pre-cooling of mango fruit}

Waskar and Dhemre (2005)

investigated effect of precooling on shelf-life of Kesar fruits and reported that the shelf life of precooled fruits after harvest was more than the un-precooled. According to Makwana et al., (2014), fruits precooled at $8^{\circ} \mathrm{C}$ for $8 \mathrm{hr}$ had longer shelf life, lower spoilage, higher percentage of marketable fruits, less physiological loss in weight and had more firmness, and also such treated fruits were taken more time (days) to ripe during storage. As the temperature of fruits after harvest regulates respiration, plays an important role in the deterioration. Atkin and Tjoelker (2003) have reported that the rate of respiration increased 2 or 3 times at every $10^{\circ} \mathrm{C}$ increment in tissue temperature. The precooling of tropical fruits like mango is, thus, most significant operation to maintain the marketable quality and extending the shelf life of mangoes (Hardenburg et al., 1986)

Consequently, several types of precooling techniques have now been invented for precooling of the agricultural produce. Room cooling, forced air-cooling, hydro cooling, running water, ice coolie, evaporative cooling, etc. are more common for the precooling of mango. Puttaraju and Reddy (1997) have studied effect of some precooling techniques [hydro-cooling (for 15 and $30 \mathrm{~min}$ ), running water (for 15 and $30 \mathrm{~min}$ ), room cooling (30 and $60 \mathrm{~min}$ ), ice cooling (15 and $30 \mathrm{~min}$ ) and evaporative cooling] on storage of mango ( $c v$. Mallika) and reported that immediate precooling after harvest delayed ripening without any decay. Similarly, Ravindra and Goswami (2008) have reported the potential of liquid nitrogen $\left(\mathrm{LN}_{2}\right)$ as another cooling medium and stated that it would be practically very useful in controlled atmosphere storage system. Its cooling capacity is very high and has inertness property of vaporized nitrogen encourages to apply with mechanical refrigeration system with the precooling techniques common for mangoes. The chilling injury, however, is a cause of concern because of its intense cold temperature. The precooling of mangoes (cv. Amrapali) using $\mathrm{LN}_{2}$ system (LN2 flow rate: $20.5 \mathrm{~kg} / \mathrm{hr}$; average temperature: $-85^{\circ} \mathrm{C}$ ) was recorded with no adverse effect on quality. In addition to above, precooling after harvest provides flexibility for market by making it possible at the optimum time. 
Table 1a: Area, production, productivity and varieties of mango in some popular state of India in the year 2010-11 (GOI, 2013) and major harvesting seasons in different states

\begin{tabular}{|c|c|c|c|c|c|}
\hline $\begin{array}{l}\text { Name of } \\
\text { the state }\end{array}$ & $\begin{array}{c}\text { Area } \\
\left(000^{\prime} h a\right)\end{array}$ & $\begin{array}{l}\text { Product- } \\
\text { ion } \\
\left(000^{\prime} t\right)\end{array}$ & $\begin{array}{l}\text { Produc- } \\
\text { tivity } \\
\text { (t/ha) }\end{array}$ & Major varieties grown & $\begin{array}{c}\text { Month of } \\
\text { harvest }\end{array}$ \\
\hline $\begin{array}{l}\text { Andhra } \\
\text { Pradesh }\end{array}$ & 399.3 & 3194.3 & 8.00 & $\begin{array}{lr}\text { 'Allumpur } & \text { Baneshan', } \\
\text { 'Banganapalli', } & \text { 'Bangalora', } \\
\text { 'Cherukurasam', } & \text { 'Himayuddin', } \\
\text { 'Suvernarekha', } & \text { 'Neelum', } \\
\text { 'Totapuri' } & \\
\end{array}$ & $\begin{array}{l}\text { April - May } \\
\text { (coastal } \\
\text { districts), May } \\
\text { (Rayalaseema) }\end{array}$ \\
\hline $\begin{array}{l}\text { Uttar } \\
\text { Pradesh }\end{array}$ & 251.5 & 2673.3 & 10.60 & 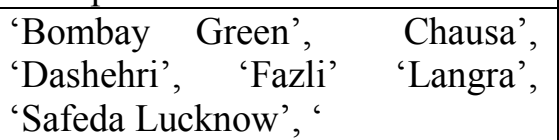 & June - August \\
\hline Karnataka & 124.5 & 1236.8 & 9.90 & $\begin{array}{l}\text { 'Alphonso', 'Bangalora', } \\
\text { 'Mulgoa', 'Neelum', 'Pairi', } \\
\text { 'Baganapalli', 'Totapuri' }\end{array}$ & May - July \\
\hline Bihar & 140.2 & 1222.7 & 8.70 & $\begin{array}{l}\text { 'Bathua', 'Bombai', 'Himsagar', } \\
\text { 'Kishen Bhog', 'Sukul', 'Gulab } \\
\text { Khas', 'Zardalu', } \\
\text { 'Maldah/Langra', 'Chausa', } \\
\text { 'Dashehri', 'Fazli', 'Kalkatia' }\end{array}$ & June - August \\
\hline Gujarat & 96 & 772.1 & 8.00 & $\begin{array}{l}\text { 'Alphonso', 'Kesar', 'Rajapuri', } \\
\text { 'Vanraj', 'Jamadar', 'Totapuri', } \\
\text { 'Neelum', 'Dashehri', 'Langra' }\end{array}$ & May - June \\
\hline Maharashtra & 444.5 & 638.6 & 1.40 & $\begin{array}{l}\text { 'Alphonso', 'Mankurad', } \\
\text { 'Mulgoa', 'Pairi', 'Rajapuri', } \\
\text { 'Kesar', 'Gulabi', 'Vanraj' }\end{array}$ & $\begin{array}{l}\text { April - May } \\
\text { (Ratnagiri) } \\
\text { May - June } \\
\text { (other areas) }\end{array}$ \\
\hline Tamil Nadu & 125.1 & 537.8 & 4.30 & $\begin{array}{l}\text { 'Banganapalli', 'Bangalora', } \\
\text { 'Neelum', 'Rumani', 'Mulgoa', } \\
\text { 'Alphonso, 'Totapuri' }\end{array}$ & April - May \\
\hline $\begin{array}{l}\text { West } \\
\text { Bengal }\end{array}$ & 70.1 & 513.3 & 7.30 & $\begin{array}{l}\text { 'Bombai', 'Himsagar', 'Kishen } \\
\text { Bhog', 'Langra', 'Fazli', } \\
\text { 'Gulabkhas', } \\
\text { 'Mallika' }\end{array}$ & May - August \\
\hline Kerala & 88 & 511.1 & 5.80 & 'Mundappa', 'Olour', 'Pairi' & March - April \\
\hline Orissa & 125.3 & 428.8 & 3.40 & $\begin{array}{l}\text { 'Baneshan, 'Langra, 'Neelum, } \\
\text { 'Suvarnarekha, 'Amrapalli, } \\
\text { 'Mallika' }\end{array}$ & May to July \\
\hline Others & 156.2 & 809.1 & 5.20 & & \\
\hline Total & 2020.7 & 12537.9 & & & \\
\hline
\end{tabular}

\section{Mango Grading}

Ripening time for bigger and smaller size fruits is different. Ripening time of fruits of larger size is 2-4 days more than the small fruits. The role of size in uniform ripening is, thus, very important. Consequently, grading of mangoes on the basis of size has its own significant role in packaging and to achieve uniform ripening. In addition to size (Fig. 2), the fruit's shape, weight, colour and maturity are the other important grading parameters of mangoes before exporting. Before exporting, mangoes are graded into three classes (Class-I: 200-250g; Class-II: 251-300g; Class III: 300$350 \mathrm{~g}$ ) as per their weight. 
Table 1b: Fruit characteristics of some exporting mango cultivars in India

\begin{tabular}{|c|c|c|c|}
\hline $\begin{array}{l}\text { S. } \\
\text { No. }\end{array}$ & $\begin{array}{c}\text { Exporting } \\
\text { Varieties }\end{array}$ & Fruit characteristics & Production area \\
\hline 1 & Alphonso & $\begin{array}{l}\text { The fruit quality is excellent and keeping quality is } \\
\text { good. It has been found good for canning purposes. }\end{array}$ & $\begin{array}{l}\text { Maharashtra, Gujarat, } \\
\text { Karnataka Madhya } \\
\text { Pradesh. }\end{array}$ \\
\hline 2 & Banganpalli & $\begin{array}{l}\text { Fruit size is large, shape is obliquely oval and colour } \\
\text { of the fruit is golden yellow. Fruit quality and } \\
\text { keeping quality are good. It is a mid season variety } \\
\text { and is good for canning. }\end{array}$ & $\begin{array}{l}\text { Andhra Pradesh and } \\
\text { Tamil Nadu. }\end{array}$ \\
\hline 3 & Chausa & $\begin{array}{l}\text { Fruit is large in size, ovate to oval oblique in shape } \\
\text { and light yellow in colour. It is a late variety. }\end{array}$ & \\
\hline 4 & Dashehari & $\begin{array}{l}\text { The fruit size is medium, shape is oblong to oblique } \\
\text { and fruit colour is yellow. Fruit quality is excellent, } \\
\text { keeping quality is good. }\end{array}$ & $\begin{array}{l}\text { Uttar Pradesh, Haryana } \\
\text { and Punjab. }\end{array}$ \\
\hline 5 & Kesar & $\begin{array}{l}\text { Fruits are medium sized, shape is oblong; flesh is } \\
\text { sweet and fibreless. Colour is apricot yellow with } \\
\text { red blush on the shoulders, good keeping quality; } \\
\text { ideal for pulping and juice concentrates; an early } \\
\text { season variety. }\end{array}$ & Gujrat \\
\hline 6 & Langra & $\begin{array}{l}\text { Fruit is of medium size, ovate shape and lettuce } \\
\text { green in colour. The lemon-yellow flesh is juicy and } \\
\text { flavourful. It is scarcely fibrous, a mid season } \\
\text { variety. }\end{array}$ & $\begin{array}{l}\text { Uttar Pradesh, Bihar, } \\
\text { Haryana, Madhya } \\
\text { Pradesh, Orissa, West } \\
\text { Bengal and Punjab. }\end{array}$ \\
\hline 7 & Malda & $\begin{array}{l}\text { Variety is alternate bearer; fruit medium, ovate and } \\
\text { yellow in colour; keeping quality medium. }\end{array}$ & $\begin{array}{l}\text { Bihar, West Bengal and } \\
\text { Madhya Pradesh. }\end{array}$ \\
\hline 8 & Neelum & $\begin{array}{l}\text { Fruit is medium ovate-oblique in shape and saffron } \\
\text { yellow in colour; good keeping quality; high } \\
\text { yielding and regular bearing; ideal variety for } \\
\text { transporting to distant places. }\end{array}$ & $\begin{array}{l}\text { Tamil Nadu, Karnataka } \\
\text { and Orissa }\end{array}$ \\
\hline
\end{tabular}

The post-harvest grading is, thus, very much important task among the steps cleaning, sorting, packing, transport, storage, waxing, etc. of mango fruit. Grading of mangoes is usually done on the basis of physical parameters such as size, shape, weight, colour, maturity, firmness, etc. However, the fruits with immaturity, over ripen, any disease and damage if found during grading are discarded (Pradeepkumar, 2008). Manual sorting and grading of mangoes is carried out in India which needed lot of man power to complete this task. Labours required sitting close to heaped mango and separating the damaged, diseased and rotten fruits by hand on the basis of tradition visual inspection norms. Sometimes fruits conveyed mechanically through the belt conveyor and visual inspection is done for picking up the undesirable produce by the labours standing both sides of the conveyor. But, in this type of visual inspection (Fig.3) is very expensive, labour intensive, and prone to human error, leading to variability in the final product. Non destructive methods can be used to do so without any biasness. 
Novel techniques in post harvest management of mango-An overview

Table 2: Nutritional Value of $100 \mathrm{~g}$ fresh mango pulp (Anon, 2001)

\begin{tabular}{|l|l|l|l|}
\hline Constituent & $\begin{array}{l}\text { Amount in 100 g } \\
\text { fresh pulp }\end{array}$ & Constituent & $\begin{array}{l}\text { Amount in 100 g } \\
\text { fresh pulp }\end{array}$ \\
\hline Water & $81.7 \mathrm{~g}$ & Vitamin A, RE & 389 mcg_RE \\
\hline Energy & $65 \mathrm{kcal}(272 \mathrm{kj})$ & Vitamin E & $1.120 \mathrm{mg}$ _ATE \\
\hline Protein & $0.51 \mathrm{~g}$ & Tocopherols, alpha & $1.12 \mathrm{mg}$ \\
\hline Fats & $0.27 \mathrm{~g}$ & Lipids & \\
\hline Carbohydrates & $17.00 \mathrm{~g}$ & Total saturated fatty acids & $0.066 \mathrm{~g}$ \\
\hline Total dietary fiber & $1.8 \mathrm{~g}$ & Total monounsaturated fatty acids & $0.101 \mathrm{~g}$ \\
\hline Ash & 0.50 & Total poly unsaturated fatty acids & $0.051 \mathrm{~g}$ \\
\hline Mineral & & Cholesterol & $0.00 \mathrm{mg}$ \\
\hline Calcium & $10 \mathrm{mg}$ & Amino acids & \\
\hline Iron & $0.13 \mathrm{mg}$ & Tryptophan & $0.008 \mathrm{~g}$ \\
\hline Magnisium & $9.0 \mathrm{mg}$ & Threonine & $0.019 \mathrm{~g}$ \\
\hline Phosphorus & $11 \mathrm{mg}$ & Isoleucine & $0.018 \mathrm{~g}$ \\
\hline Potassium & $156 \mathrm{mg}$ & Leucine & $0.031 \mathrm{~g}$ \\
\hline Sodium & $2 \mathrm{mg}$ & Lysine & $0.041 \mathrm{~g}$ \\
\hline Zinc & $0.04 \mathrm{mg}$ & Methionine & $0.005 \mathrm{~g}$ \\
\hline Copper & $0.11 \mathrm{mg}$ & Phenylalanine & $0.017 \mathrm{~g}$ \\
\hline Mangnese & $0.027 \mathrm{mg}$ & Tyrosine & $0.01 \mathrm{~g}$ \\
\hline Selenium & $0.6 \mathrm{mcg}$ & Valine & $0.026 \mathrm{~g}$ \\
\hline Vitamins & & Arginine & $0.019 \mathrm{~g}$ \\
\hline $\begin{array}{l}\text { Vitamin C (total } \\
\text { ascorbic acid) }\end{array}$ & $27.2 \mathrm{mg}$ & Histidine & $0.012 \mathrm{~g}$ \\
\hline Thiamine & $0.056 \mathrm{mg}$ & Alanine & $0.051 \mathrm{~g}$ \\
\hline Riboflavin & $0.57 \mathrm{mg}$ & Aspartic acid & $0.042 \mathrm{~g}$ \\
\hline Niacin & $0.584 \mathrm{mg}$ & Glutamic acid & $0.06 \mathrm{~g}$ \\
\hline Pantothenic acid & $0.16 \mathrm{mg}$ & Glycine & $0.021 \mathrm{~g}$ \\
\hline Vitamin B 6 & $0.16 \mathrm{mg}$ & Proline & $0.018 \mathrm{~g}$ \\
\hline Total folate & $14 \mathrm{mcg}$ & Serine & $0.022 \mathrm{~g}$ \\
\hline Vitamin A, IU & $3894 \mathrm{IU}$ & & \\
\hline & & & \\
\hline
\end{tabular}

These sophisticated novel technologies have developed for quick, accurate and efficient evaluation of agricultural produce to avoid the chance of human error. Various non-invasive techniques have now been emerged very strongly for the quality assessment of agricultural produce and also for other sectors of agriculture to achieve the above objectives (Patel et al., 2019a). For instance, machine/computer vision system, magnetic resonance imaging/nuclear magnetic resonance, near infrared, ultra sound, electronic nose and eye, X-ray and computed tomography, etc. (Anonymous, 2016; Patel et al., 2012b). Figure 3 shows a glimpse of computer vision vs. human vision.

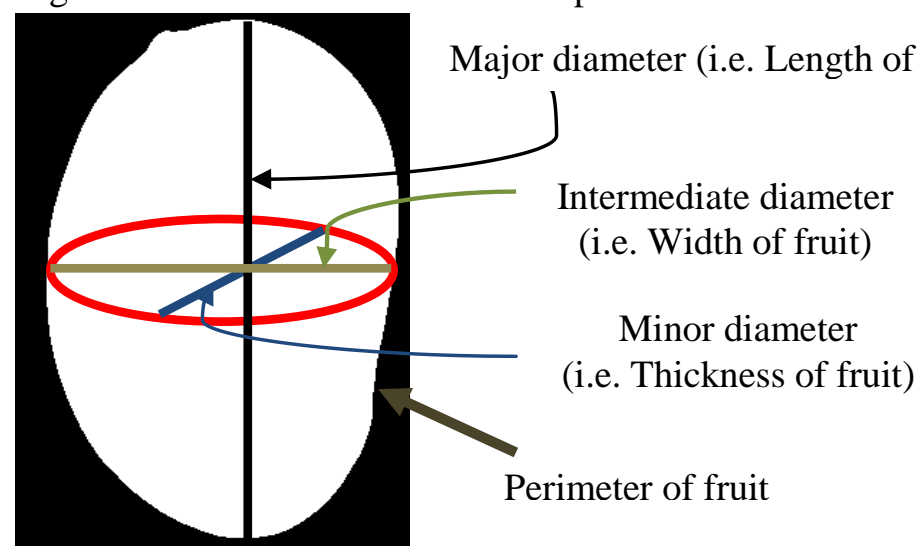

Fig. 2 Some geometrical attributes of mango fruit 
Further, the main physical damages, responsible for post harvest losses of mango, the important parameter of grading, are physiological decay, water loss and over ripening (GOI, 2013). These damages may occur at any point of marketing process and during handling and transport. In addition, other serious causes of mangoes are the postharvest diseases among the growers and the diseases are cause of concern during storage and transportation too. These issues, thus, limit the thriving mango industry. A range of leaf, fruit and soil disease can also be affected the quality of mango fruit or can induce disease after harvesting. Anthracnose, latex stain/sap burn, stem-end-rot, chilling injury, fruit rot, cut wounds, stem end cavity, mealy-bug, hot water injury, mango scab, bacterial black spot, powdery mildew, etc are the unacceptable defects/disease/disorders causing the lowering of prices of fruits. Brief descriptions of some major diseases are given below.

a. computer vision system

(Abdullah, 2008)

\section{b. Human vision system}

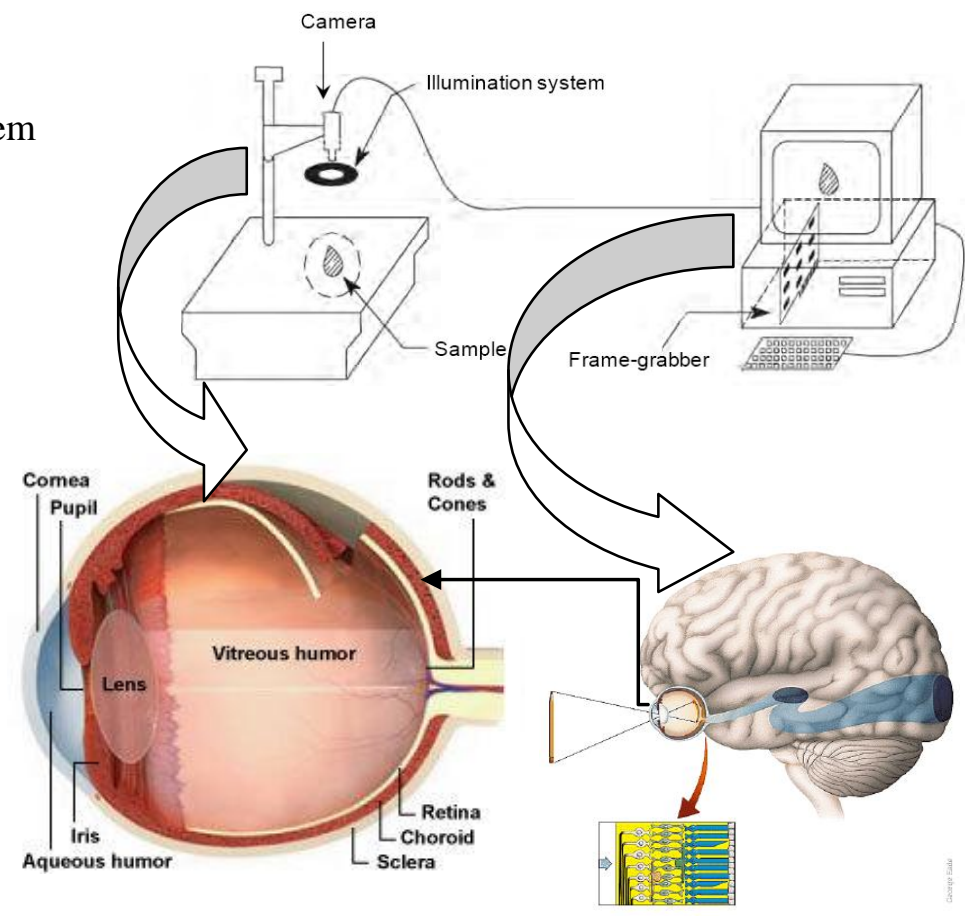

Fig. 3: Computer vision vs. human vision system

Post-harvest disease/decay of mangoes

Anthracnose (black lesion): Fungus, Colletotrichum gloeosporioides (teleomorph: Gloeomerello cingulata) (Arauz, 2000). Fungus (C. gloeosporiodes) is responsible for many diseases of mangoes and of many tropical fruits and is referred as anthracnose (Nelson, 2008). Anthracnose causes serious decay during marketing and after sale of fruits. The effect of anthracnose under wet condition of fruits is more serious and produces conspicuous pinkish-orange spore (Corkidi et al., 2006). Anthracnose infected panicle, leaves and fruits from $20^{\circ}$ to $30^{\circ} \mathrm{C}$ temperature and more than 95\% RH (Dodd, 1991). In the field, anthracnose infections are favored by wet, humid, warm weather conditions while post-harvest anthracnose development generally favored by warm and humid temperatures (Corkidi et al., 2006). Post harvest anthracnose, similarly, causes black to brown lesions on the surface. These surface spots eventually penetrate and mingle, and cause huge losses. Post harvest anthracnose is actually similar pre-harvest anthracnose when infected young fruits in the field and remains in quiescent stage until ripening (Prusky, 1996). Fruits appear healthy at harvest; thus, can develop rapid considerable anthracnose symptoms during ripening. It has been reported that most of the infected green remains latent and mostly hidden until ripening. Anthracnose infected ripened fruits develop sunken, dark brown to black spots. Mature fruits when infected caused significant losses during storage, transportation and marketing because transfer of fungus into the 
storage. Sometimes maturity, however, restricted the disease to the peel and becomes evident during storage. However, a serious anthracnose infection invaded into the pulp and further advancement develops acervuli and orange to salmon pink masses of conidia on lesions (Arauz, 2000).

Table 3 Non-destructive technologies for defects detect and quality assessment of mangoes

\begin{tabular}{|c|c|c|c|}
\hline $\begin{array}{c}\text { S. } \\
\text { No. }\end{array}$ & Technique & Target & References \\
\hline 1. & $\begin{array}{l}\text { Reflected UV imaging } \\
\text { at } 400 \mathrm{~nm}\end{array}$ & $\begin{array}{l}\text { Detection of anthracnose (black lesion), } \\
\text { latex stain, fungal stricken area, shriveled } \\
\text { fruit and dried tissues beneath the peel } \\
\text { surrounding the defected area. } \\
\text { - Detection of Scratch on surface/crack or } \\
\text { cut on surface or beneath the peel of } \\
\text { fruit. }\end{array}$ & Patel et al., (2019a) \\
\hline 2. & Colour CVS & - Physical characterization of mangoes & Patel et al., (2019b) \\
\hline 3. & 3-D image analysis & $\begin{array}{l}\text { - Spot-like lesions on the surface of } \\
\text { mango. }\end{array}$ & Corkidi et al., (2016) \\
\hline 4. & $\begin{array}{l}\text { Automatic } \\
\text { Multiclass support } \\
\text { vector machine (SVM) }\end{array}$ & - Grading of mangoes. & $\begin{array}{l}\text { Agilandeeswari et } \\
\text { al., (2017) }\end{array}$ \\
\hline 5. & $\begin{array}{l}\text { Colour camera based } \\
\text { CVS and image } \\
\text { processing }\end{array}$ & - Detection of bacterial canker disease & $\begin{array}{l}\text { Nadarajan and } \\
\text { Thamizharasi (2017) }\end{array}$ \\
\hline 6. & $\begin{array}{l}\text { Colour camera based } \\
\text { CVS and image analysis }\end{array}$ & $\begin{array}{l}\text { - Defect identification and maturity } \\
\text { detection. }\end{array}$ & $\begin{array}{l}\text { Sahu and Potdar } \\
\text { (2017) }\end{array}$ \\
\hline \multirow[t]{2}{*}{7.} & \multirow[t]{2}{*}{$\begin{array}{l}\text { Digital X-ray imaging } \\
\text { technique }\end{array}$} & - Stone weevil in mango fruit. & $\begin{array}{l}\text { Sambrani et al., } \\
(2015)\end{array}$ \\
\hline & & $\begin{array}{l}\text { - Spongy Tissue in fruit like Alphonso } \\
\text { mango. }\end{array}$ & $\begin{array}{l}\text { Musale and Patil } \\
(2014)\end{array}$ \\
\hline 8. & $\begin{array}{l}\text { Colour camera based } \\
\text { Computer Vision } \\
\text { System (CVS) and } \\
\text { image processing }\end{array}$ & $\begin{array}{l}\text { - Determination of surface defects (black } \\
\text { spot or scratches). }\end{array}$ & Nandi et al., (2014) \\
\hline 9. & $\begin{array}{l}\text { UV-light using a low- } \\
\text { cost webcam }\end{array}$ & - Anthracnose and latex stain. & Nagle et al., (2012) \\
\hline 10. & NIR Technology & $\begin{array}{l}\text { - Determining the starch and dry matter } \\
\text { content of immature and mature } \\
\text { mangoes. }\end{array}$ & $\begin{array}{l}\text { Slaughter et al., } \\
\text { (2009) }\end{array}$ \\
\hline 11. & MRI Technology & $\begin{array}{l}\text { - Heat treatment induced injury to } \\
\text { mesocarp tissue. }\end{array}$ & Joyce et al., (1993) \\
\hline
\end{tabular}

Latex burn (staining): Sap burn, a serious quality concern (Maqbool and Malik, 2007), is the largest single quality problem with mango. Mango latex is a clear, slightly milky and viscous fluid which is responsible for allergic action on the skin (Loveys et al., 1992) and can inflict serious eye effect (Menezes et al., 1995). Poor harvesting and handlings result in a high incidence of sap burn which downgrades the fruit quality severely (Johnson and Parr, 2006). Sap is caustic in nature and has aroma characteristics of ripe fruit while oozes out instantly from unripe fruit as soon as the fruit is detached from stalk. Sap can be separated into two phase lower (milky and viscous) and upper phase (clear, yellow-brown and oily) by centrifugation at 12000rpm for 5 min (Loveys et al., 1992). Upper phase is more responsible for sap burn than lower phase. When sap comes in contact with the fruit during harvesting and post-harvest handling causes undesirable skin blemish or 
burn (Anon, 2003). Sap classified as spurt sap and ooze sap (Bagshaw, 1989). Spurt sap released rapidly after skin injuries and stem removal within 5 second while ooze sap released slowly over about one hour. Ooze sap does not harm the skin but spurt sap burn the fruit and leave a blemish which further advanced during storage and transportation and leads huge losses (GOI, 2013).

Further, the amount and composition of sap exuded by a fruit depends on fruit maturity, harvest time of day, cultivar, and harvest season and production region. The less mature fruit generally exuded more sap and the harvesting of fruit early in the morning has greater sap flow than later during the day (Bagshaw, 1989). In order to avoid exudation of latex onto the fruit, the pedicel should be pointed downward at the time of removal, placed on de-sapping bench to drain out sap and then fruit should be washed to avoid the chance of any sap burn (GOI, 2013). Maximum sap burn took place within the first 24 hour of sap contact but the injury continue even after 72 hour of sap contact in Chausa and Sindhuri cultivars of mango. Thus extra care must be taken during first 24 hour of harvest. De-stemming under $\mathrm{Ca}(\mathrm{OH})_{2}$, Tween20 and Tween-80 can be most effective treatments against sap burn in both cultivars (Maqbool and Malik, 2007). Sap burn avoided by using latex/sap dynamics in Ambalavi and Chembaddan mangoes. For Karuthakolumban mangoes, de-stemming and dipping in the 5\% $\mathrm{NaCl}$ (table salt) is very effective for reducing of sap burn injury. Similarly, the $1 \%$ table salt has been reported effective for Willard mangoes to reduce sap burn without affecting quality (Krishnapillai and Wijeratnam, 2016).

Stem-end-rot: Different fungi, Dothiorella spp., Lasiodiplodia theobromae (Johnson and Cooke, 1991; Ploetz et al., 1994) or phomopsis mangiferae (Ploetz et al., 1994; Ko et al., 2009), are responsible for stem-end-rot and for several post harvest mango diseases alongwith anthracnose. Complex pathogens (Botryosphaeriocaeae (De Oliveira Costa, 2010), L. theobromae, $N$. mangiferae, Neofusicoccum parvum and Fusicoccum aesculi) are found to be associated with stemend-rot reported several studies. Stem-end-rot in Austrian mangoes, for instance, associated with $N$. parvum and $F$. aesculi, $N$. mangiferae (Slippers et al., 2005) and Stem-end-rot dieback disease of mango in Brazil was associated with $L$. theobromae, $N$. parvum and $F$. aesculi pathogens (De Oliveira Costa, 2010). Amin et al., (2011) reported A. alternate, $P$. mangifera, Botryodiplodia spp. as main pathogens associated with stem-end-rot in agro-ecological conditions of Punjab (Pakistan). Although, the disease started after attacking of fungus on fruit stem prior to harvest or on mechanically injured site. The initial symptom of disease is darkening of skin around the base of pedicel. Infected area enlarges rapidly and forms circular brownishblack lesion area of water soaked tissues which extended to whole fruits as time passed and at last fruits rotten within some days after entering the fungus at stem (Anon, 2003). During ripening, endophytic colonization of inflorescence and pedicel tissues found to be primary route of infection. However, $30^{\circ} \mathrm{C}$ temperature reported to be in favour of $L$. theobromae pathogen. Infection can be reduced by leaving a pedicel of 1 bout $1-2 \mathrm{~cm}$ (Yahia, 2005).

Chilling injury: Chilling injury, physiological induced disorder (Yahia, 2005) of mango fruit is occurring at storage temperatures below about $10-13^{\circ} \mathrm{C}$ (Mann and Singh, 1976) or $10^{\circ} \mathrm{C}$ (Hulme, 1971) or $11^{\circ} \mathrm{C}$ (Anonymous, 2003) according to Ji et al., (1994), fruit stored at $8^{\circ} \mathrm{C}$ developed no chilling injury symptoms. In contrast, Kane and Marcellin (1978) have reported that storage of mango at $4^{\circ} \mathrm{C}$ and $8^{\circ} \mathrm{C}$ developed chilling injury after 10 days. Chilling injury is also responsible for pitting, sunken lesion, uneven ski color, internal darkening, decay, and off-flavour and leakage of metabolites (amino acids, mineral salts and sugars) from cell structure. Similarly, Medlicott (1990) reported that chilling injury inhibited ripening when all harvests stored at $8^{\circ} \mathrm{C}$ and when early season harvests stored at $10^{\circ} \mathrm{C}$. The better storage temperature of mangoes, harvested at mid- and late session, to avoid chilling injury is $10^{\circ} \mathrm{C}$ and $12^{\circ} \mathrm{C}$. Temperature and storage period are the main factors responsible for severity of chilling injury. Storage at lower temperature for longer period causes more chill injury (Anon, 2003). Although, it has been reported that some cultivars such as: Dashehari, Langara, etc. can safely be stored at $7-8^{\circ} \mathrm{C}$ for 25 days. The enhanced resistance to the chilling injury might be related to the higher the total soluble 
solids content in fruit (Mukherjee and Srivastava, 1979).

Furthermore, temperature of hydrocooling water found to be directly responsible for chilling injury and thus it should be maintained at $10^{\circ} \mathrm{C}$ (DeEll et al., 2000). The hot water treatment of Dashehari and Langara fruits usually control the chilling injury during storage at low temperature. Exogenous putrescine treatments can also be used to avoid chilling injury. Since, putrescine treatment inhibit ethylene production and maintained superoxide dismutase activity in pericarp at a higher level and retard the malondialdehyde content and membrane permeability. In addition, mango fruit when wrapped in microperforated poly ethylene/ or Xtend film and stored in modified/controlled atmosphere of $5 \% \mathrm{CO}_{2}$ and $10 \% \mathrm{O}_{2}$ can also reduce the possibility chilling injury (Pesis et al., 2000). In addition, high temperature $\left(35-38^{\circ} \mathrm{C}\right)$ conditioning for few hours before low temperature storage shows better results (Yahia, 2005).

Alternaria rot: In the absent or well controlled of anthracnose and stem-end rot disease, Alternaria rot caused by Alternaria alternate can cause significant post-harvest decay in mango (Prusky et al., 2009). In other words, A. alternate can cause serious/huge losses during storage for three or more weeks (Yahia, 2005) and compromise the storage life of fruits (Prusky et al., 1981; Kobiler et al., 2001). The casual organism of black spot and stem-end-rot disease is A. alternate.

Through lenticels of fruits, $A$. alternate penetrates the fruit, darkens the intercellular spaces and collapses the cell. Appearance of disease consists of either black spot (diameter: $0.5-1.0 \mathrm{~mm}$ ) with dark centre and diffusive border or dark lenticels (Yahia, 2005). Initially spots were noticed to be concentrated around the stem of fruits where high numbers of lenticels are present and later these spots grow, coalesce and become large spot, and cover half of the fruit. .As time passed disease extended into the flesh and darkens and becomes partially soft (Anon, 2003).

Further, Diedhiou et al., (2007) conducted a study to understand better the interaction between fungi involved in the post harvest rotting of mango, local production practices and climate changing conditions during the maturation period. Their study reported that the fruit harvested during humid season were infested more and the cultural practices played important role. Orchard sanitation, particularly cleaning and pruning reduced the infection rates.

Mansour et al., (2006) isolated A. alternate alongwith Botrydiplodia theobromae and Botrytis cinerea from rotten mangoes (Meitt, Kent and Tommy Atkins. They reported that these are highly pathogenic to all these varieties. They further reported that when fruits were treated with hot air $\left(50^{\circ} \mathrm{C}\right.$ for $4 \mathrm{hr}$ ) followed by hot water $\left(40^{\circ} \mathrm{C}\right.$ for $\left.5 \mathrm{~min}\right)$ in combination were found more effective in retarding of post harvest disease without peel darkening, fruit damage and affecting the uninoculated fruit's qualities (TSS, titratable acidity, vitamins $\mathrm{C}$ content, etc) and found to be increased shelf life of inoculated and uninoculated fruits. Alternaria rot can also be controlled using combination of physical (1520 s spraying of hot water of $50-55^{\circ} \mathrm{C}$ temperature and brushing) and chemical (prochloraz, chlorine, etc.) treatments. This new approach enhances the quality of fruits in the same manner as it reduced disease incidence (Prusky et al., 2009).

In addition to above, several researchers such as Patel et al., (2019a) Agilandeeswari et al., (2017), Nadarajan and Thamizharasi (2017), Sahu and Potdar (2017), Sambrani et al., (2015), Musale and Patil (2014), Nandi et al., (2014), Nagle et al., (2012), Slaughter, (2009), Corkidi et al., (2006), Joyce et al., (1993) have reported techniques for quality assessment and defect detection of mangoes (Table 3). For instance, Patel et al., (2019a) have studied the potential of reflected ultra-violet imaging for surface defect (mechanical damage, black lesion, latex stains, and shriveling) detection of mangoes responsible for post harvest losses and lowering of market prices. In their study they detected the exact seriousness of injuries unable to detect by RGB colour camera by reflected UV imaging technique at $400 \mathrm{~nm}$ band-pass filter (Table 3). In addition, computer vision system (CVS) can also be used for evaluation of size attributes (length, width, thickness), various morphological features (area, perimeter, Max Feret diameter, hydraulic radius, Waddel disk diameter, elongation factor, compactness, factor, Heywood circularity factor and type factor) of 
mangoes (Chausa and Dashehari) (Patel et al., 2020).

\section{Packaging}

Packaging means all those activities related to designing, evaluating and producing the container for a product. Packaging protects every fruits from rub, contact and any type of compression and damage. In addition, it avoids fruits from dirt, dust, pests, contaminants, etc. Wooden boxes, CFB (corrugated fibre boxes), polythene (low density), crates, etc are used for packaging of graded fruits (Gill et al., 2005). For mango fruit, wooden boxes are more common for packaging and transportation in the domestic market. However, CFB is now need of an hour because of lack of wood and more worry about the environment condition. The CISH (Central Institute for Subtropical Hrticulture), Lucknow has designed CFBs of the capacity of 5 and $10 \mathrm{~kg}$ for mangoes and presented best alternative to traditional nailed wooden boxes (Medina and Garcia, 2002). Anonymous (2006) has reported extensive use of CFBs for export purposes. For packaging and transportation of Alphonso mangoes, CFBs were also found to be best and suitable than the wooden boxes (Roy and Pal, 1991). Cushioning material (paper wraps, newspapers, etc.) generally used in the course of packaging to prevent bruising and spoiling during storage and transportation (Gill et al., 2005; Ravindra and Goswami, 2007). However, the low density polyethylene (LDPE) lining maintains humidity and results lesser fruit shrinkage during storage. Polyethylene packaging, thus, gave the best storage to the products retaining the moisture content and sensorial attributes. Similarly, the individual fruit wrapping (uni-pack) using newspaper or tissue paper and honeycomb nets packing helps in ripening with reduced spoilage (Medina and Garcia, 2002; Narayana et al., 1991). But, sealing of mature green fruit in semi-permeable polyethylene can cause quality deterioration in terms of taste and appearance (Anonymous, 2006; Straten and Osthuyse, 1994). Thus, the use of clean, new and qualitative materials particularly paper or stamps with trade specifications should be allowed. The printing or labeling should be allowed with non-toxic ink or glue to avoid any internal and external damage. Recommended International Code of Practice for Packaging and Transport of Fresh Fruits and Vegetables (CAC/RCP 44-1995, Amd. 12004) should follow during mangoes packaging in container.

\section{Storage}

Storage is an activity through which consumption period increased; market supply is regulated and transportation to long distances achieved. The main objective of storage, however, is to arrest damage and extend the shelf life of agricultural produce. Various storage techniques (low temperature/pressure storage, CA/MA: controlled atmosphere/ modified atmosphere, and use of chemicals, wraps and coatings and ionizing radiation) have been emerged for horticultural produces, so far. Pre-cooling of horticultural crops is required first and then storage before exporting. Dasehari, Mallika and Amrapali should be stored at $12^{\circ} \mathrm{C}$, Langra at $14^{\circ} \mathrm{C}$ and Chausa at $8^{\circ} \mathrm{C}$ with 85 95\% RH. At low temperature, fruits can be stored for 3-4 weeks in good condition.

According to Kader et al., (2002), temperature of storage for mature green mango is $13^{\circ} \mathrm{C}$ and $10^{\circ} \mathrm{C}$ for partially and fully ripe mango fruit with $90-95 \% \mathrm{RH}$ is recommended. The $90 \% \mathrm{RH}$ and $10-15^{\circ} \mathrm{C}$ temperature from ambient condition could be achieved in zero energy cool chambers (ZECC) when watering is done twice a day. Using local materials (bricks, sand, bamboo, dry grass, juite, etc.), IARI New Delhi developed ZECC. The ZECC works on the principle of evaporation. After performance evaluation of ZECC in various parts of country, it has been reported that the shelf life of mangoes can be increased by 3-4 days (Roy and Pal, 1991). Economical, in terms of construction and operation, and its satisfactory performance resulted developments of a variety of various ZECC models of capacity between $100 \mathrm{~kg}$ and 1000 $\mathrm{kg}$. These were tested and found performed equally well in reducing post harvest losses and maintaining the quality of fruits and vegetables. Improved type ZECC is one of them and satisfactory storage at $7-8 \%{ }^{\circ} \mathrm{C}$ has also been reported (Mann and Singh, 1976).

CA/MA (controlled atmosphere/modified atmosphere) can also be recommended for better results. Since, CA provides an effective storage environment (Bender et al., 2000; Raghavan et al., 2003) while the role of MA is to maintain the quality of fruits after harvest is very significant (Ding et al., 2002; Rodov et 
al., 2002). For instance, storage under controlled atmosphere (3-4 \% $\mathrm{CO}_{2}$ and $4-5 \%$ $\mathrm{O}_{2}$ ) with a continuous flow system at $13-15^{\circ} \mathrm{C}$ is found to be very effective in prolonging the shelf life of Alphonso cultivar for 30 days including 4 to 5 days ripening period. Lalel $e t$ al., (2001) has recommended atmospheric composition $6 \% \mathrm{CO}_{2}$ and $2 \% \mathrm{O}_{2}$ for enhancing the shelf life of mangoes (cv. Kesington Pride). For CA/MA storage of mango, an atmospheric composition of 4-10\% $\mathrm{CO}_{2}$ and 1$8 \% \mathrm{O}_{2}$ have been studied and recommended by Lalel et al., (2005), Bender et al., (2000), etc. in varying combinations for a given cultivar and maturity of fruits. For instant, optimum matured fruit do no exhibit symptoms of chilling injury, have longer storage shelf life and may withstand maximum limit (25\%) of $\mathrm{CO}_{2}$ (Roy and Pal, 1991) showed insecticidal effects during storage (Yahia and Vazquez-Moreno, 1993). However, storage of mango in the atmospheric composition of $15 \% \mathrm{CO}_{2}$ and $1 \% \mathrm{O}_{2}$ results quality degradation in terms of off-flavor and skin discoloration. Modified packaging inhibited the mango ripening process (Sornsrivichai et al., 1992).

\section{Transportation}

Mango transportation needs careful handling to avoid damage and spoilage. Mangoes in ripening stage become too soft during transportation and are susceptible to easy injury that reduces the eating and keeping quality (Anon, 2012). Prior to loading of treated mangoes packets, a careful inspection of empty trucks or vans is needed to ensure that these are free from pest and any type of biological debris. For this purpose, before exporting the mangoes from India to USA a joint inspection by the Animal and Plant Health Inspection Service (USDA: United State Department of Agriculture) and Plant Protection, Quarantine and Storage, Ministry of Agriculture (NH IV, Faridabad) is carried out. Similarly, the second disinfection is required for empty van or truck if any pests are found in the first round inspection. Thorough disinfection of empty van of truck is ensured/ or effectively controlled using suitable insecticide. All suspected areas such as space between doors, every nook and corner, etc. should be disinfected carefully. The loading area should be covered by inspect-proof screen for the prevention of hitchhiking pest entry during loading. The doors of van or truck is closed and secured by a lock after loading. Finally a seal required to be fixed.

\section{Conclusion}

The roles of novel techniques for post harvest management of mangoes are very important to maintain its economical and nutrition value in national and international markets. To reduce the losses after harvest, sustaining the overall value (nutritional and economical) and extending the shelf life of mangos, application of these novel practices could be very effective and the profits of growers and marketers consequently increased. For local markets a simple washing of mangoes, however, only required to remove dust, dirt and latex spot if any. But, for the exporting of mangoes various post harvest treatment/management activities for mangoes are required. For example, mangoes are dipped in hot water containing fungicide to control disease. As hot water reduced the chances of damage/infection due fruit fly, anthracnose, stem-end-rot, etc, the hot water treatment has been found an effective treatment after harvest for mangoes. The post harvest activities (precooling, sorting, grading, packaging, storage and transportation, etc.), therefore have important impact on quality management and add values before marketing of mangoes. This paper presents an overview of recent applied technologies for post harvest management of mangoes and it could be the basis for mango grower and marketer.

\section{References}

Agilandeeswari, L., Prabukumar, M. and Goel, S. (2017). Automatic grading system for mangoes using multiclass SVM classifier. International Journal of Pure and Applied Mathematics, 116 (23): 515-523.

Amin M, Malik AU, Khan AS and Javed N (2011) Potential of Fungicides and Plant Activator for Post-harvest Disease Management in Mangoes. International Journal of Agriculture Biology, 13:671676.

Anonymous (2001). USDA Nutrient Database for Standard Reference, Release 14 July 2001.

Anonymous (2003) Mango: post-harvest care and market preparation. Ministry of 
Fisheries, Crops and Livestock; the New Guyana Marketing Corporation (NGMC) and the National Agricultural Research Institute (NARI), Post-harvest Handling Technical bulletin No. 3.

Anonymous (2006). Mango. www.ficciagroindia.com/post-harvestmgmt/fruits/mango.htm. Accessed 15 January 2006

Anonymous (2012). Transportation of mango. http://mango-trees.blogspot.in/2012/01/ transportation-of-mango.html. Accessed 25 March 2018.

Anonymous (2016). Mango:Post-harvest \& Processing. http://www.itfnet.org/ v1/2016/05/mango-post-harvestprocessing/. Accessed 24 March 2018.

Arauz, L.F. (2000). Mango anthracnose: economic impact and current options for integrated management. Plant Disease, 84(6): 600-611

Atkin, O.K. and Tjoelker, M.G. (2003). Thermal acclimation and the dynamic response of plant respiration to temperature. Trends Plant Science, 8(7): 343-351

Bagshaw, J. (1989). Mango pests and disorders. Queensland Department of Primary Industries, p.44 (Bulletin, Q189007).

Bender, R.J., Brecht, J.K., Sargent, S.A. and Huber, D.J. (2000). Low temperature controlled atmosphere storage for treeripe mangoes (Mangifera indica $\mathrm{L}$ ). Acta Horticulture, 509: 447-458.

Corkidi, G., Balderas-Ruiz, K.A., Taboada, B. and Serrano-Carreón, L and Galindo, E. (2006). Assessing mango anthracnose using a new three-dimensional imageanalysis technique to quantify lesions on fruit. Plant Pathology, 55:250-257

De Oliveira Costa, V.S.O., Michereff, S.J., Martins, R.B., Gava, C.A.T., Mizubuti, E.S.G and Camara, M.P.S. (2010) Species of Botryosphaeriaceae associated on mango in Brazil. European Journal of Plant Pathology, 127: 509-519

DeEll, J.R., Vigneault, C. and Lemerre, S. (2000). Water temperature for hydrocooling field cucumbers in relation to chilling injury during storage. Postharvest Biology and Technology, 18:2732
Diedhiou, P.M., Mbaye, N., Dramel, A. and Samb, P.I. (2007). Alteration of post harvest diseases of mango Mangifera indica through production practices and climatic factors. African Journal of Biotechnology, 6(9): 1087-1094.

Ding, C.K., Chachin, K., Ueda, Y., Imahori, Y. and Wang, C.Y. (2002). Modified atmosphere packaging maintains postharvest quality of loquat fruit. Postharvest Biology and Technology, 24 (3): 341-348.

Dodd, J.C., Estrada, A.B., Matcham, J., Jeffries, P. and Jeger, M.J. (1991). The effect of climatic factors on Colletotrichum gloeosporioides, causal agent of mango anthracnose, in the Philippines. Plant Pathology, 40:56875.

Food and Agricultural organization (F.A.O.). (2017). Food outlook: Biannual report on global food markets, http://www.fao.org/3/a-I8080e.pdf. Accessed date 16 February 2018.

Gill, P.S., Singh, P.N. and Jawandha, S.K. (2005). Post harvest handling of mangoa review. Proceedings: International conference on mango and date palm: culture and export, 20th to 23rd June, Milk et al. (eds), University of Faisalabad.

Government of India (GOI). (2013). PostHarvest profile of mango-report. Directorate of Marketing \& Inspection Branch head office Nagpur, 1-141. https://agmarknet.gov.in/Others/prefacemango.pdf. Accessed date 12 February 2018.

Hardenburg, R.E., Watada, A.E. and Wang, C.Y. (1986). The Commercial Storage of Fruits, Vegetables, and Florist and Nursery Crops. In: USDA Agriculture Handbook No. 66: 72. Beltsville.

Hulme, A.C. (1971). The mango. In: Biochemistry of fruits and their products. Academic Press, London and New York, pp 233-253.

Jagtiani, J., Chan, H.T. and William, J.S.S. (1988). Tropical fruit processing. Academic press INC. Harcourt Brace Jovanovich, Publishers San Diego, New York, Berkly, Boston, London, Sydney, Tokyo, Toranto. 52-73.

Ji, Z.L., Znang, Z.Q., Wang, Y. and Li, X.P. (1994). Low temperature storage and 
chilling injury of mangoes. Acta Horticulture Sinica, 21:111-116.

Johnson, P.R. and Parr, D. (2006). Mango growing in Western Australia. Department of agriculture and Food, Western Australia, Bulletin 4348

Joyce, D.C., Hockings, P.D., Mazucco, R.A., Shorter, A.J. and Brereton, I.M. (1993). Heat treatment injury of mango fruit revealed by nondestructive magnetic resonance imaging. Post-harvest Biology and Technology, 3:305-311.

Kader, A.A., Sommer, N.F. and Arpaia, M.L. (2002). Post-harvest handling systems: tropical fruits. In: A.A.Kader (ed), Postharvest technology of horticultural crops, third edition. University of California, Agriculture and Natural Resources, Publication 3311: pp.385398.

Kane, O. and Macellin, P. (1978). Incidence of ripening and chilling injury on the oxidative activities and fatty acid composition of mitochondriya from mango fruits. Plant Physiology, 61:634640

Ko, Y., Liu, C.W., Chen, C.Y., Maruthasalam, S. and Lin, C.H. (2009). First report of stem-end rot of mango caused by Phomopsis mangiferae in Taiwan. Plant Disease, 93: 764

Kobiler, I., Shalom, Y., Roth, I., Akerman, M., Vinokur, Y., Fuchs, Y. and Prusky, D. (2001). Effect of 2,4dichlorophenoxy acetic acid on the incidence of side and stem end rots in mango fruits. Post-harvest Biology and Technology, 23: 23-32.

Krishnapillai, N. and Wijeratnam, R.S.W. (2016). Sap burn injury management of mangoes (Mangifera indica L.) in Sri Lanka. Pakistan Journal of Botany, 48(5):2147-2152

Lalel, H.J.D., Singh, Z. and Tan, S.C. (2001). Elevated level of $\mathrm{CO}_{2}$ in controlled atmosphere storage affects the shelf life, carotenoids and fruit quality of mango. Acta Horticulture, 553:605-606

Lalel, H.J.D., Singh, Z. and Tan, S.C. (2005). Controlled atmosphere storage affects fruit ripening quality of Deelta 'R2E2' mango. Journal of Horticulture Science and Biotechnology, 80: 551-556

Loveys, B.R., Robinson, S.P., Brophy, J.J. and Chacko, E.K. (1992). Mango sap burn:
Components of fruit sap and their role in causing skin damage. Australian Journal of Plant Physiology, 19:449-457

Makwana, S.A., Polara, N.D. and Viradia, R.R. (2014). Effect of Pre-Cooling on Post Harvest Life of Mango (Mangifera Indica L.) CV. Kesar. Food Science and Technology, 2(1): 6-13

Mann, S.S. and Singh, R.N. (1976). The cold storage life of Dashehari mangoes. Scientia Horticulturae, 5: 249-254

Mansour, F.S., Abd-El-Aziz, S.A. and Helal, G.A. (2006). Effect of fruit heat treatment in three mango varieties on incidence of postharvest fungal disease. Journal of Plant Pathology, 88 (2): 141148

Maqbool, M. and Malik, A.U. (2007). Evaluation of some potential chemicals for reducing sap burn injury in mango. Proceeding: International Symposium on Prospects of Horticultural Industry in Pakistan, 28th -30th March, Institute of Horticultural Sciences, University of Agriculture, Faisalbad.

Medina, J.D.L.C. and Garcia, H.S. (2002). Mango: Post-harvest Operations. Food and Agricultural Organization of the United Nations

Medlicott, A.P. (1990). Ripening of mangoes following low temperature storage. Journal of American Society for Horticulture Science, 115(3): 430-434.

Menezes, J.B., Alves, R.E. and Freire, F.C.O. (1995). Mango sapburn-a post-harvest injury. Revista Brasileira de Fisiologia Vegetal, 7: 181-184.

Mitra, S.K. (2016). Mango production in the world - present situation and future prospect. Acta Horticulturae, 11(11): 287-296.

Mukherjee, P.K. and Srivastava, R.B. (1979). Increasing the storage life of mango (Mangifera indica L.) by lowering the critical temperature. Progressive Horticulture, 10: 63-69.

Musale, S,S, and Patil, P.M. (2014). Database development of defective and healthy alphonso mangoes. International Journal of Advances in Agricultural \& Environmental Engineering, 1(1):155160.

Nadarajan, A.S. and Thamizharasi, A. (2017). Detection of bacterial canker disease in mango using image processing. IOSR 
Journal of Computer Engineering, 19(2):1-8

Nagle, M., Intani, K., Mahayothee, B., Sardsud, V. and Muller, J. (2012). Nondestructive mango quality assessment using image processing: inexpensive innovation for the fruit handling industry. Conference Int Res Food Security, Natural Res Management and Rural Development (Tropentag 2012), Gottingen (Germany), September 19-21, p.1-4.

Nandi, C.S., Tudu, B. and Koley, C. (2014). Computer vision based mango fruit grading system. International conference on Innovative Engineering Technologies (ICIET'2014) Dec. 28-29, 2014 Bangkok (Thailand).

Narayana, C.K., Roy, K. and Pal, R.K. (1991) .Use of high molecular weight highdensity polyethylene (H-M-film) in transit of mango (cv. Baneshan). Acta Horticulturae, 291:489-492.

Nelson, S.C. (2008). Mango anthracnose (Colletotrichum gloeosporiodes). Published by College of Tropical Agriculture and Human Resource (CTAHR). Plant Disease, PD-48.

Patel, K.K., Kar, A. and Khan, M.A. (2012a). Nondestructive food quality evaluation techniques: Principle and Potential. Agriculture Engineering Today, 36(4) : 29-34

Patel, K.K., Kar, A. and Khan, M.A. (2020). Development and an Application of Computer Vision System for Nondestructive Physical Characterization of Mangoes. Agricultural Research, 9: 109-124

Patel, K.K., Kar, A., Jha, S.N. and Khan, M.A. (2012b). Machine vision system: a tool for on-line sorting and grading of agricultural foods and produces. Journal of Food Science and Technology, 49(2):123-141.

Patel, K.K., Kar, A. and Khan, M.A. (2019a). Potential of reflected UV imaging technique for detection of defects on the surface area of mango. Journal of Food Science and Technology, 56(3):12951301.

Pesis, E., Aharon, D., Aharo, Z., Ben-Arie, R., Aharoni, N. and Fuchs, Y. (2000). Modified atmosphere and modified humidity packaging alleviates chilling injury symptoms in mango fruit. Postharvest Biology and Technology, 19: 93101

Ploetz, R.C., Zentmyer, G.A., Nishijima, W.T., Rohrbach, K.G. and Ohr, H.D. (1994). Compendium of Tropical Fruit Diseases. American Phytopathological Society Press. St. Paul, Minnesota, pp.118.

Pradeepkumar, T. (2008). Management of Horticultural Crops: Vol.11 Horticulture Science Series: In 2 Parts, New India publishing, p.106.

Prusky, D. (1996). Pathogen quiescence in post-harvest diseases. Annual Review of Phytopathology, 34: 413-34

Prusky, D., Ben-Aire, R. and Guelfat-Reich, S. (1981). Etiology and histology of Alternaria rot of persimmon fruits. Phytopathology, 71: 1124-1128.

Prusky, D., Falik, E., Kobiler, I., Fuchs, Y. and Zauberman, G. (1997) Hot water brush: a new method for control of post-harvest diseases caused by Alternaria rot in mango fruits. Acta Horticulturae, 455: 780-785.

Prusky, D., Kobiler, I., Miyara, I. and Alkan, N. (2009). Fruit diseases. In: Litz, R.E. (ed.), The Mango: Botany, Production and Uses, 2nd edition, pp: 210-230.

Puttaraju, T.B. and Reddy, T.V. (1997). Effect of precooling on the quality of mango cv. 'Mallika'. Journal of Food Science and Technology, 34(1): 24-27.

Raghavan, G.S.V., Gariepy, Y. and Vigneault, C. (2003). Controlled atmosphere storage. In : Encyclopedia of agricultural, food and biological engineering. Marcel Dekker, Inc., New York, p. 148.

Ravindra, M.R. and Goswami, T.K. (2007) Post harvest handling and storage of mangoes-an overview. Journal of Food Science and Technology, 44(5): 449458.

Ravindra, M.R. and Goswami, T.K. (2008). Comparative performance of precooling methods for the storage of mangoes (Mangifera indica L. cv. Amrapali). Journal of Food Process Engineering, 31(3): 354-371.

Rodov, V.B., Horev, Y.V., Copel, A., Aharoni, Y. and Aharoni, N. (2002). Modified atmosphere packaging improves keeping quality of Charentais- 
type melons. Horticultural Science, 37(6):950-953

Roy, S.K. and Pal, R.K. (1991). A low cost zero energy cool chamber for short term storage of mango. Acta Horticulture, 291:519-524.

Sahu, D. and Potdar, R.M. (2017) Defect Identification and Maturity Detection of Mango Fruits Using Image Analysis. American Journal of Artificial Intelligence, 1(1):5-14

Sambrani, S., Dhumwad, S., Navalli, B., Shivraj, H.J. and Kanakaraddi, S.G. (2015). Detection of stone weevil in mango fruit using non-destructive technique. International Journal of Emerging Technology in Computer Science \& Electronics, 14 (2): 204-208.

Slaughter, D.C. (2009). Nondestructive Maturity Assessment Methods for Mango: A Review of Literature and Identification of Future Research Needs". Biological and Agricultural Engineering of California, Davis.

Slippers, B., Johnson, G.I., Crous, P.W., Coutinho, T.A., Wingfield, B.D. and Wingfield, M.J. (2005). Phylogenetic and morphological re-evaluation of the Botryosphaeria species causing diseases of Mangifera indica in Australia. Mycologia, 97: 99-110.

Sornsrivichai, J., Gomolmanee, S., Boonyakiat, D., Uthaibutra, J., Boonlong, P. and Gemma, H. (1992). Seal Packaging by plastic film as a technique for limiting fungal decay of mangoes. Acta Horticulturae, 296:24-32

Straten, B.V. and Osthuyse, S.A. (1994). The effect of cold storage at 4 of 8 degree on the rate of quality deterioration of ripe sensation mango fruit. South African mango growers association year book, 14: 34-36.

Waskar, D.P. and Dhemre, J.K. (2005). Effect of precooling on extending the postharvest life of kesar mango fruits. Indian Journal of Agricultural Research, 39(1):42-6.

Yahia, E.M. (2005). Postharvest technology and handling of mango, In Oris R (Ed), Crops: Quality, growth and biotechnology, WFL Publisher, Helsinki, Finland, pp. 478-512.

Yahia, E.M. and Vazquez-Moreno, L. (1993) Tolerance and responses of mango to insecticidal oxygen and carbon dioxide atmospheres.

Lebensm-Wiss 